\title{
THE CREATIVITY INDEX GROWTH RATE IN THE CZECH REPUBLIC: A SPATIAL APPROACH
}

\author{
Markéta CHALOUPKOVÁ, Josef KUNC ${ }^{1}$, Zdeněk DVOŘÁK ${ }^{1}$
}

DOI: 10.21163/GT_2018.131.04

\begin{abstract}
:
The presented paper analyses the development of conditions for the development of a creative economy in the regions of the Czech Republic. Through the calculations of a number of sub-indicators in the area of talent, technology and tolerance (Florida's 3T model), the development of the Creativity Index in 2011-2015 has been mapped in individual regions. In the next phase the development of the average growth rate of the Creativity Index was evaluated and graphically illustrated. At the end of the research, a situational and trending matrix of creativity was compiled, dividing the regions into four quadrants (leaders, up and coming, laggards, and losing ground). The results showed the dominant position of the capital city of Prague, which reached the highest score throughout the whole period and with great precedence surpassed all other regions. Only the South Moravian Region surpassed Prague in a specific way, in the value of the R \& D indicator. In this region lies the second largest city of the Czech Republic in Brno, which has a very strong position in the field of research, development and innovation. The situational matrix captured the situation in which the leader's quadrant was only Prague, while the other regions were growing in the region quadrant. On the contrary, the trend matrix has suggested that Prague is losing its leading position as it is overtaken by the South Moravian region.
\end{abstract}

Key-words: Creativity Index, $3 T$ Model (Talent, Technology, Tolerance), Spatial Approach, Czech Republic

\section{INTRODUCTION}

Since the end of the last century, the economies of developed countries (in the last decade and many transforming post-socialist countries) have undergone significant changes in connection with the growing importance of industries based on innovation, knowledge, information, digitization and creativity. There is a so-called knowledge-based economy, learning economy, creative economy, or digital economy (Lundvall \& Johnson, 1994; OECD, 1996; Mackinnon \& Cumbers, 2007; Veselá \& Klimová, 2014; Carayannis et al., 2018). Most countries have great potential for developing a creative or knowledge-based economy that is based on its cultural, social and geographical context. Also, culture and, together with it, the so-called cultural and creative industries gain more and more attention as "engines of economic development", which are largely involved in creating prosperity and having a positive impact on the economy (Lampel \& Germain, 2016; Liu, 2018). In the area of regional and urban development and planning, the cultural and creative industries are referred to as a new type of competitive advantage and source of innovation and competitiveness of companies, cities and regions (Bocella \& Salerno, 2016).

\footnotetext{
${ }^{1}$ Masaryk University, Faculty of Economics and Administration, 60200 Brno, Czech Republic, marketa.chaloupkova@mail.muni.cz; kunc@econ.muni.cz;dvorak.zdenek@mail.muni.cz
} 
The term "cultural industry" was first used to criticize the commodification and unification of culture in 1944 by members of the Frankfurt School of Critical Theory by Theodor Adorn and Max Horkheimer in their book Dialectics of Enlightenment. During the 1960s and 1970s, the cultural industry was replaced by a plurality of cultural industries. Using a single number did not explain the complexity and diversity of the range of human activities that belong to this group (Hesmondhalgh, 2007). The boom of the cultural industries was largely related to the changes that society has undergone since the economic crisis of the 1970s. This is a period that is a typical shift from industrial to postindustrial, respectively information society, and based mainly on knowledge. Also, the production structure has changed significantly and industrial production has retreated to services. Consumers have begun to put much more pressure on modernization, quality, diversity and added value, a change that the culture sector has also had to react to (Power \& Scott, 2004). The cultural sector has been seen as a potential means of economic development, especially in cities and metropolitan areas (Markusen et al., 2008).

European academics, urban planners and politicians began promoting the development of cultural sites and activities in the late 1980s as an appropriate way of revitalizing especially deprived post-industrial cities (Markusen et al., 2008). Investments in cultural industries were therefore included among local and regional development policy tools to regenerate cities and create job. (Selwood, 2006; Cikánek, 2013). Since the early 1990s, the growing influence of intangible corporate assets, particularly the value of brand names, has gained momentum. (Coyle, 1999). Social scientists from various disciplines (cultural studies, economics, sociology, or geography) have begun to emphasize the growing importance of culture, meaning, and symbols in the development of modern capitalism. (Leriche \& Daviet, 2010).

The beginnings of the Creative Cities Concept are linked to the British Comedia Consultancy Group, which in the 1990s began to push the emphasis on incorporating art and culture into urban development strategies, which in turn will lead to economic growth that will depend on Creativity and Innovation in the 21st century (Hesmondhalgh, 2007). The idea of creative clusters draws on the theory of Michael Porter's industrial clusters, as local concentrations of interconnected companies and institutions in a particular field (Porter, 1990). Once cities and regions have had music festivals, galleries, or theatres, thanks to strategies for the development of culture and creativity, they have moved to the next stage of local development in which they have moved on to the creative class and those involved in the creative industries. (Florida, 2002; Hesmondhalgh, 2007; Cikánek, 2013).

At present, there is still no uniform view of the creative / cultural industries. Disagreements lie in the very designation of this area (cultural industries, creative industries, copyright industries and others) as well as in the definitions and enumerations of industries falling between the creative industries. Experts have gradually introduced and defined other key concepts such as creative cities (Landry, 2000; Scott, 2000), core creative arts a core creative industries (Throsby, 2001), patent and copyright industries (Howkins, 2001), creative class as a motor of urban regeneration (Florida, 2002), or model applications through the creativity index (Florida, 2002) and its modification of the creativity city index (Landry, 2011).

A number of newer works are not primarily theoretically and methodological, but they focus on case studies from selected cities and regions on creativity, smart and innovative practices in urban politics and planning, often geographic, spatial context (Rumpel et al., 2010; Angelidou, 2014; Tafel-Viia et al., 2015; Dörry, 2016). Spatial and planning studies 
from rapidly growing Asian cities and metropolitan areas are also topical (Tang, 2016; Zhong, 2016; Fahmi et al., 2016 and many others).

Conditions for developing a creative economy at the state, region, or city level can be measured using different models and indexes. The above-mentioned Creativity Index is a new statistical indicator for the assessment and interpretation of the regions' growth determinants. The original Creativity Index was compiled by Florida (2002), using the 3T talent, technology and tolerance model. This model was further expanded by other indicators within the next Euro-creativity index (Florida \& Tinagli, 2004). The aim of our contribution is to analyse the development of conditions for the development of a creative economy in the regions of the Czech Republic by modifying and applying the 3T Model to the specifics of the Czech Republic, in particular by analysing the average rate of growth of the Creativity Index. To capture the development and the possibility of data interpretation, a five-year time period (2011-2015) was chosen.

\section{METHODS AND DATA}

In order to achieve the set goal, it was first necessary to calculate the overall Creativity Index. The methodology for calculating the overall Creativity index was inspired, in particular, by Florida (2002) and Kloudová (2009). The calculation of the index has been modified for research purposes in the Czech Republic. The overall index was calculated using six sub-indicators divided into three areas (talent, technology and tolerance).The data for the calculation of the individual indicators were mainly derived from the Czech Statistical Office, the Industrial Property Office of the Czech Republic, and the migration portal of the Ministry of the Interior. The calculation of these sub-indexes is shown in Table 1 below.

Table 1.

Method of Creative index sub-indexes calculation.

\begin{tabular}{|c|c|c|}
\hline \multirow{2}{*}{ Talent } & $\begin{array}{l}\text { Human } \\
\text { (HCI) }\end{array}$ & $\begin{array}{l}\text { Ratio of population with university education in } \\
\text { the region to the total population of the region }\end{array}$ \\
\hline & Creative class index $(\mathrm{CCI})$ & $\begin{array}{l}\text { Ratio of creative professionals in the region to the } \\
\text { total employment of the region }\end{array}$ \\
\hline \multirow{2}{*}{ Technology } & $\begin{array}{l}\text { Research and } \\
\text { development index (R\&D) }\end{array}$ & $\begin{array}{l}\text { Ratio of research and development spending to } \\
\text { the GDP of the region }\end{array}$ \\
\hline & Innovation index (INI) & $\begin{array}{l}\text { Number of patent applications per inhabitant of } \\
\text { the region }\end{array}$ \\
\hline \multirow{2}{*}{ Tolerance } & Gay index (GI) & $\begin{array}{l}\text { Share of registered partnerships in the region on } \\
\text { the total population of the region }\end{array}$ \\
\hline & Immigration index (IMI) & $\begin{array}{l}\text { The share of foreign migrants in the region on the } \\
\text { total population of the region }\end{array}$ \\
\hline
\end{tabular}

Source: Florida (2002), edited

The aggregate Creativity index calculation was based on the average value of its subindexes. The order of individual regions was determined by the results of the Creativity index calculation. The values of the calculated indexes were converted to values between 0 and 1 using the standardized Min-Max method (OECD, 2008) for all regions of the Czech Republic, which allows to capture the distance between regions. 


$$
N_{i}=\frac{X_{i}-\operatorname{MIN}\left(\forall_{i} X_{i}\right)}{\operatorname{MAX}\left(\forall_{i} X_{i}\right)-\operatorname{MIN}\left(\forall_{i} X_{i}\right)}
$$

The calculation of the Creativity index was necessary for a follow-up analysis of the average growth rate of the Creativity index, which was calculated as the average growth coefficient multiplied by a hundred. The average growth coefficient for the time series (2011-2015) was calculated as the geometric average of the individual growth coefficients. The calculation of the average growth rate was therefore based on the following formula:

$$
\bar{k}=\sqrt[n-1]{\prod_{t=2}^{n} k_{t}}=\sqrt[n-1]{\frac{y_{n}}{y_{1}}}
$$

The average increment rate was calculated as the average increment coefficient multiplied by hundred. The average increment coefficient was calculated as the average growth rate minus one. The negative result of the measured indicator can be more precisely interpreted as a decrease. The final step of the Creativity index analysis was to build a situational and trend matrix of creativity (Creativity Matrix). The situational matrix capturing the state of the Czech Republic's regions in 2015 is not suitable for the interpretation of development (although it is commonly used in practice), as it cannot capture the development over time (Kloudová, 2009).

To identify a positive or negative shift regarding the past (or baseline of 2011), a trend matrix was developed to capture the evolution of the average growth rate in 2011-2015. To build this matrix, it was necessary to calculate the Creativity trend index first. This indicator is limited to the areas of talent and technology (i.e. 2T). The reason for omitting the tolerance indicator is a great difficulty to measure the development of human attitudes (Kloudová, 2009). Thus, the Creativity trend index is the sum of the average values of $\mathrm{R} \& \mathrm{D}$, innovation, human capital, and creative class. Average of these values should reduce the distortion that could occur in the event of unexpected or cyclical fluctuations. The Creativity Matrix is constructed by plotting the Creativity index on the $\mathrm{x}$-axis and the trend values of the Creativity index on the y-axis. The obtained graph is therefore divided into 4 quadrants (leaders, growth, lagging and land-losing) in which the regions are assigned.

\section{RESULTS AND DISCUSSION}

Based on the above-mentioned methodology, the Creativity index was measured for all regions of the Czech Republic (see Table 2). In the surveyed period (2011-2015), the capital city of Prague, which is a separate region with a concentration of offices of multinational companies, foreign capital, research and development centres. Its dominant position is also supported by the low values of the Creativity index measured in the Central Bohemia region, which can be regarded as a backdrop of Prague and is largely "vacuumed". After the partial indicators analysis, we can state that South Moravian region surpassed Prague in the value of the R\&D indicator, probably due to higher subsidies, which is probably due to higher subsidies flowing to the region from EU funds and to which Prague did not have access in earlier years. The South Moravian region shows the 
second highest values of the Creativity index over the entire monitored period, which is primarily the second largest city of the Czech Republic in Brno, where the R \& D, innovation and knowledge economy sectors are concentrated. The third position is held by the Liberec region, which reaches high values especially in the Creative class index, respectively that is the share of creative employment to total employment in the region, and R\&D index (maximum in 2012). It is a region with good connections to Prague, where industrial enterprises, nowadays tied to hi-tech, innovative technologies and foreign capital, concentrate in the context of the historical tradition. The region also houses the largest industrial enterprise in the country - Škoda Mladá Boleslav (automotive industry) with a large research and development base. On the other hand, the Vysočina Region consistently shows the lowest values which can be described as probably the most rural.

Table 2.

\section{Creativity index in the regions of the Czech Republic.}

\begin{tabular}{|c|c|c|c|c|c|c|}
\hline Name of the region & Abbreviation & $\mathbf{2 0 1 1}$ & $\mathbf{2 0 1 2}$ & $\mathbf{2 0 1 3}$ & $\mathbf{2 0 1 4}$ & $\mathbf{2 0 1 5}$ \\
\hline Prague & PHA & 0.98 & 0.95 & 0.95 & 0.96 & 0.98 \\
\hline Central Bohemia & STC & 0.26 & 0.25 & 0.26 & 0.23 & 0.24 \\
\hline South Bohemia & JHC & 0.25 & 0.19 & 0.18 & 0.21 & 0.25 \\
\hline Plzeň & PLK & 0.36 & 0.28 & 0.23 & 0.28 & 0.34 \\
\hline Karlovy Vary & KVK & 0.21 & 0.24 & 0.15 & 0.16 & 0.24 \\
\hline Ústí nad Labem & ULK & 0.19 & 0.22 & 0.11 & 0.24 & 0.22 \\
\hline Liberec & LBK & 0.39 & 0.31 & 0.32 & 0.34 & 0.40 \\
\hline Hradec Králové & HKK & 0.21 & 0.18 & 0.24 & 0.19 & 0.24 \\
\hline Pardubice & PAK & 0.20 & 0.24 & 0.17 & 0.18 & 0.21 \\
\hline Vysočina & VYS & 0.06 & 0.06 & 0.05 & 0.04 & 0.05 \\
\hline South Moravia & JMK & 0.48 & 0.46 & 0.47 & 0.46 & 0.49 \\
\hline Olomouc & OLK & 0.18 & 0.22 & 0.19 & 0.19 & 0.22 \\
\hline Zlín & ZLK & 0.20 & 0.17 & 0.20 & 0.18 & 0.19 \\
\hline Moravia-Silesia & MSK & 0.22 & 0.25 & 0.23 & 0.24 & 0.24 \\
\hline
\end{tabular}

It is also interesting to keep track of development in the last two years of measurement, as between 2014 and 2015; there was a significant positive shift in the South Bohemia, Plzeň, Karlovy Vary, Hradec Králové, South Moravian, and Liberec regions. The reason for this significant shift is a strong increase in the creative class that is in the talent field, which supports Florida's idea regardingthe existence of so-called creative centres. Florida (2002) considers creative centres as diverse, tolerant, and open places for new ideas, leading to concentration of creative capital, and consequently to greater pressure to innovation, development of high-tech technologies and to economic, social, and environmental growth.

The next phase of the survey was to compare the growth rate of the Creativity index. The highest average growth rate of the Creativity index was measured in the Olomouc region (1.05), followed by Karlovy Vary (1.04) and Ústí nad Labem (1.04) regions. On the contrary, the lowest average growth rate was recorded in Vysočina (0.95), Central Bohemian (0.98), and Plzeň (0.98) regions. For all regions of the Czech Republic, the average increment rate of the Creativity index was also measured. Table 3 and Fig. 1, 
shows regions that have been shifted upwards (shown by yellow shades) and regions that have experienced a decrease (shown by blue shades). The highest values of the average increment rate were recorded in the Olomouc region (5.10) and the lowest values in the Vysočina region (-5.37).

Table 3.

Average increment rate of the Creativity index in the regions of the Czech Republic.

\begin{tabular}{|c|c|c|c|c|c|c|c|c|}
\hline $\begin{array}{l}\text { Name of the } \\
\text { region }\end{array}$ & $\begin{array}{l}\text { Abbre- } \\
\text { viation }\end{array}$ & $\begin{array}{c}\text { Growth } \\
\text { rate } \\
2011\end{array}$ & $\begin{array}{c}\text { Growth } \\
\text { rate } \\
2012\end{array}$ & $\begin{array}{c}\text { Growth } \\
\text { rate } \\
2013\end{array}$ & $\begin{array}{c}\text { Growth } \\
\text { rate } \\
2014\end{array}$ & $\begin{array}{c}\text { Growth } \\
\text { rate } \\
2015\end{array}$ & $\begin{array}{c}\text { Average } \\
\text { growth } \\
\text { rate }\end{array}$ & $\begin{array}{c}\text { Average } \\
\text { rate of } \\
\text { increment }\end{array}$ \\
\hline Prague & PHA & - & 0.97 & 1.00 & 1.01 & 1.02 & 1.00 & 0.00 \\
\hline $\begin{array}{r}\text { Central } \\
\text { Bohemia }\end{array}$ & STC & - & 0.94 & 1.06 & 0.88 & 1.05 & 0.98 & -1.93 \\
\hline $\begin{array}{c}\text { South } \\
\text { Bohemia }\end{array}$ & $\mathrm{JHC}$ & - & 0.78 & 0.93 & 1.15 & 1.21 & 1.00 & 0.37 \\
\hline Plzeň & PLK & - & 0.78 & 0.82 & 1.19 & 1.22 & 0.98 & -1.68 \\
\hline Karlovy Vary & KVK & - & 1.15 & 0.62 & 1.10 & 1.47 & 1.04 & 3.91 \\
\hline $\begin{array}{l}\text { Ústí nad } \\
\text { Labem }\end{array}$ & ULK & - & 1.16 & 0.52 & 2.15 & 0.92 & 1.04 & 4.34 \\
\hline Liberec & LBK & - & 0.78 & 1.03 & 1.08 & 1.17 & 1.00 & 0.47 \\
\hline $\begin{array}{l}\text { Hradec } \\
\text { Králové }\end{array}$ & HKK & - & 0.85 & 1.33 & 0.77 & 1.29 & 1.03 & 2.79 \\
\hline Pardubice & PAK & - & 1.16 & 0.70 & 1.08 & 1.18 & 1.01 & 0.91 \\
\hline Vysočina & VYS & - & 0.90 & 0.82 & 0.90 & 1.21 & 0.95 & -5.37 \\
\hline South Moravia & JMK & - & 0.94 & 1.03 & 0.98 & 1.07 & 1.00 & 0.35 \\
\hline Olomouc & OLK & - & 1.24 & 0.83 & 1.04 & 1.14 & 1.05 & 5.10 \\
\hline Zlín & ZLK & - & 0.86 & 1.16 & 0.90 & 1.08 & 0.99 & -0.86 \\
\hline $\begin{array}{l}\text { Moravia- } \\
\text { Silesia }\end{array}$ & MSK & - & 1.11 & 0.94 & 1.03 & 1.01 & 1.02 & 2.10 \\
\hline
\end{tabular}

Source: own calculations 


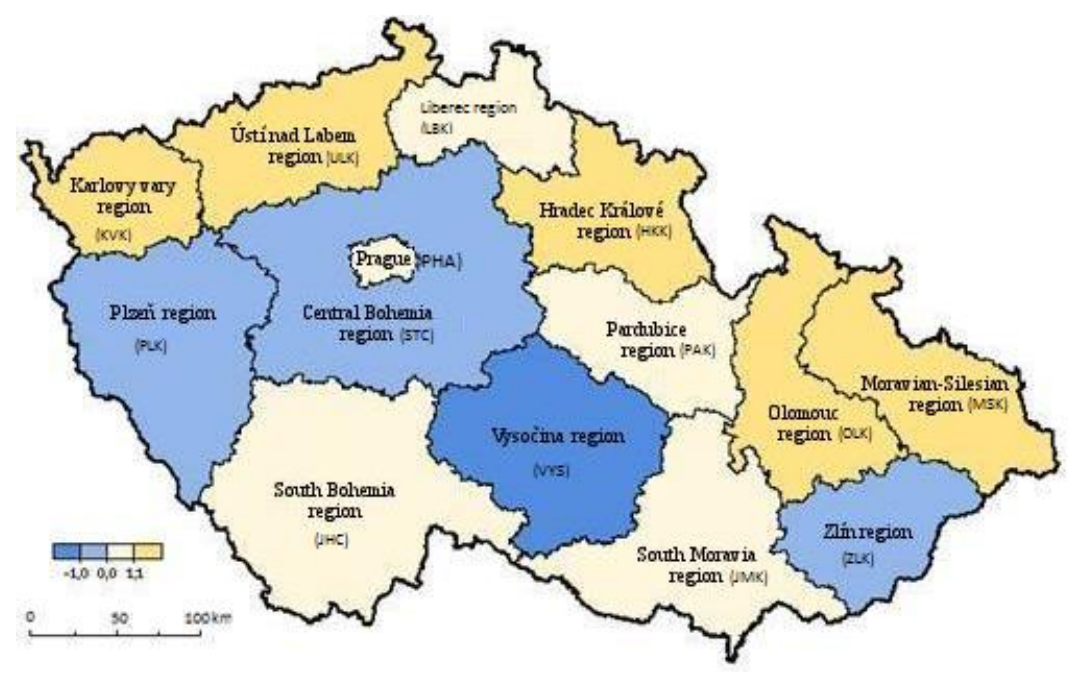

Fig. 1. Average increment rate of the Creativity index in the regions of the Czech Republic.

(Source: own processing)

The obtained values of the aggregate Creativity index measured for individual regions of the Czech Republic were subsequently used in the last step of the analysis, in which the situational and trend matrix of creativity was created (Fig. 2). The situation matrix shows that only Prague is in the quadrant of leaders, while the other regions are growing region quadrant. Based on the results, it is expected that the South Moravian region and the Liberec region will continue in catching up Prague region. On the contrary, the Vysočina Region is very close to the quadrant of the lagging regions, which may signal another weakening of the region's position in the future.

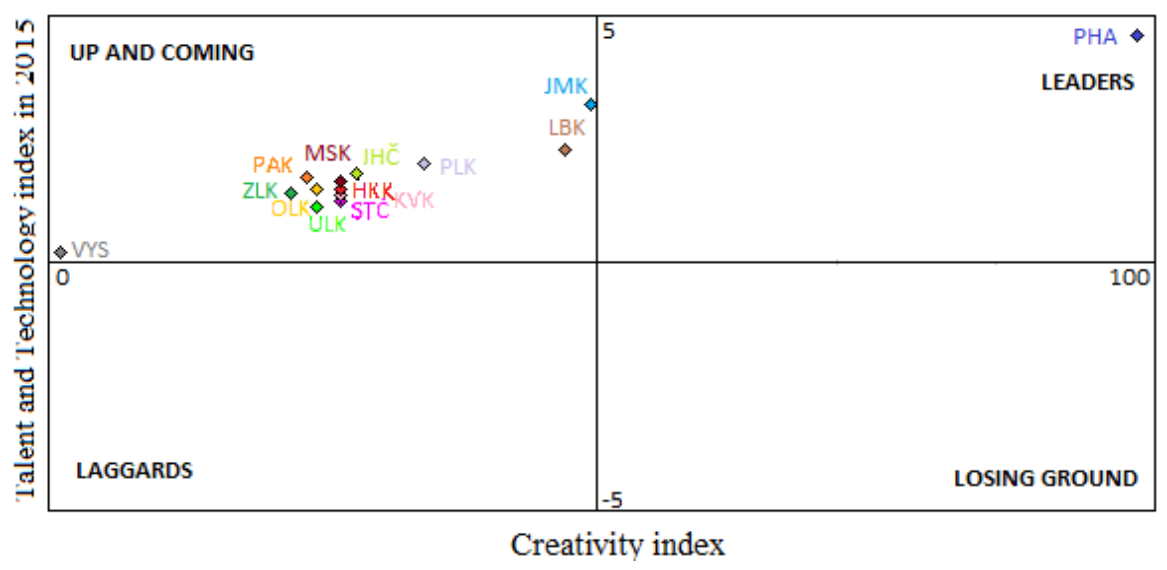

Fig. 2. Situational creativity matrix for the regions of the Czech Republic.

(Source: own calculations) 
Based on the results shown in the trend matrix (see below, Fig. 3), it can be said that Prague region is slightly losing its leading position because the South Moravian region, positioned in the growth quadrant, is catching up. All other regions are also positioned in the growth quadrant, which is a significant positive shift than the one found in the Kloudová (2009), which included a trend matrix for the period 2001 to 2007. Ústí nad Labem, Karlovy Vary, and Plzeň regions experienced the greatest improvement. They were positioned in the lagging quadrant during 2001-2007. The reason for the upward trend is an investment increase into the development of the region, the effort of the region to attract the creative class and, consequently, to increase the economic prosperity of the region, as could be for example seen in studies (Leriche and Daviet, 2010; Rumpel et al., 2010; Tafel-Viia et al., 2015; Krzysztofik et al., 2016).

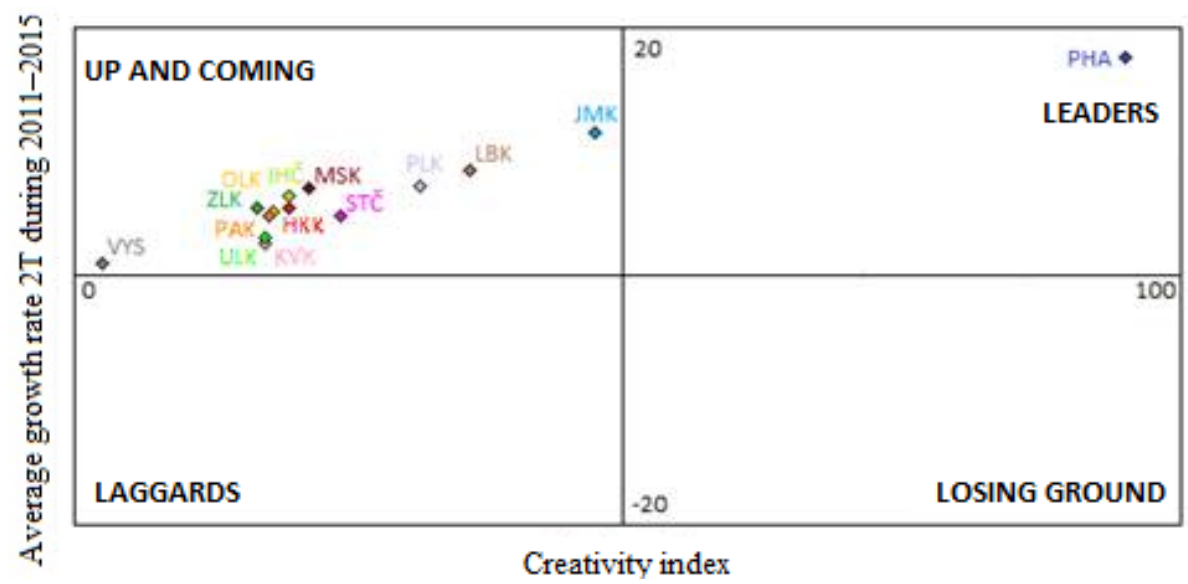

Fig. 3. Trend creativity matrix for regions of the Czech Republic (2011-2015).

(Source: own calculations)

\section{CONCLUSIONS}

In today's era of globalization, it is confirmed that creativity and innovation are the driving force of a creative economy. Organizations, regions, cities and urban agglomerations use creativity to generate significantly higher revenues and ensure greater stability in the future (Tonev et al., 2017). Creative economics (including various sustainable and smart aspects) is unique in that it relies on an unlimited resource, ie human creativity, which also gives rise to a significant multidimensional approach to studying changes in the context of economic, geographical, demographic, cultural or social (Van der Pol, 2007; Ponzini \& Rossi, 2010; Turón \& Gomis, 2016).

Although Landry (2011), as one of the leading representatives of creative research, speaks in his theoretical contribution of 25 years of research and defines, for example, ten key indicators to assess creative urban dynamics, statistical coverage of creative sectors at international level is still a problem, challenge. This is mainly due to the fact that creativity has fairly clear inputs, but not uniform and easily quantifiable outputs. The manifestations 
of creativity can be found in all economic spheres or sectors (primary, secondary, tertiary) which makes it very difficult to identify them (Kloudová, 2009).

One of the basic methodological approaches to measuring creativity is the 3T Modelbased Creativity Index (see above), which was compiled by Florida (2002) and later modified to the Euro-creativity index (Florida \& Tinagli, 2004). Consequently, Hui et al. (2004) created the so-called "5Cs Model" Creativity Index, which extends Florida's indicators, especially in the area of non-economic factors (human, institutional / structural, cultural and social capital). However, any modification or extension entails increased demands on the base and comparable data available. Therefore, most studies using the original $3 \mathrm{~T}$ model or modified version of Florida are geared to assessing creativity at the level of one state, region or city (Tinagli et al., 2007; Rumpel et al., 2010; Tinagli et al., 2012; Fahmi et al., 2016; Dörry et al., 2016). The comparison of creative potential and human capital in the EU-27 was attempted by Bobirca \& Draghici (2011), while their modification was called the European Creativity Trend Index. Leading Scandinavia and Benelux countries have been at the forefront, on the other hand, the last countries of South East Europe and the Baltic States. However, research by Romanian scientists uses data from the period 10-15 years ago, and the upward movement of post-socialist Europe can be expected today.

The results of our research in the regions of the Czech Republic showed the dominant position of the City of Prague, which reached the highest score over the whole period and prevailed with great predominance over all other regions. Only the South Moravian Region surpassed Prague in a specific way, in the value of the R \& D indicator. In this region lies the second largest city of the Czech Republic in Brno, which has a very strong position in the field of research, development and innovation. The situational matrix captured the situation where only the Prague was in the quadrant of leaders, while the other regions were growing in the region quadrant, which is a significant shift compared to the methodically similarly designed study Kloudová (2009). On the contrary, the trend matrix has suggested that Prague is losing its leading position as it is overtaken by the South Moravian region. However, the other regions also saw a shift in the growth quadrant of the regions.

In conclusion, it is possible to generalize, as many authors quote in their works, that if regions are to continue to improve and to be more competitive in the "creative age" they should continue to invest in research, development and innovation, which would subsequently contribute to increasing the potential of human capital and upward movement. Similarly, as in the past 10 years, the regions in the Czech Republic have succeeded.

\section{ACKNOWLEDGEMENTS}

This contribution was supported by an internal grant of the Faculty of Economics and Administration, Masaryk University, entitled "Cities, municipalities, regions: management, processes and interactions in theory and practice“ (MUNI/A/0994/2017).

\section{REFERENCES}

Angelidou, M. (2014) Smart city policies: A spatial approach. Cities, 41, S3-S11.

Bobirca, A., Draghici, A. (2011) Creativity and economic development. International Journal of Economics and Management Engineering, 5(11), 1447-1452.

Boccella, N., Salerno, I. (2016) Creative Economy, Cultural Industries and Local Development. Procedia - Social and Behavioral Sciences, 223, 291-296. 
Carayannis, E.G., Ferreira, J.J.M., Jalali, M.S., Ferreira, F.A.F. (2018) MCDA in knowledge-based economies: Methodological developments and real world applications. Technological Forecasting and Social Change, (In Press).

Cikánek, M. (2013) Kreativni prưmysly: př́ležitost pro novou ekonomiku. II. nové, rozšířené a revidované vydání. Praha: Institut umění, 2013

Coyle, D. (1999) The weightless world: strategies for managing the digital economy. Cambridge, MA: MIT Press.

Dörry, S., Rosol, M., Thissen, F. (2016) The significance of creative industry policy narratives for Zurich's transformation toward a post-industrial city. Cities, 58, 137-142.

Fahmi, F.Z., Koster, S., van Dijk, J. (2016) The location of creative industries in a developing country: The case of Indonesia. Cities, 59, 66-79.

Florida, R. (2002) The Rise of the Creative Class-and how it's transforming work, leisure, community and everyday life. New York: Basic Books.

Florida, R., Tinagli, I. (2004) Europe in the Creative Age. London: Carnegie Mellon Software Industry Center/DEMOS.

Howkins, J. (2001) The creative economy: how people make money from ideas. London: Penguin.

Hesmondhalgh, D. (2007) The cultural industries. Los Angeles: Sage.

Hui, D., NG, Ch-H., Mok, P. (2004) A Study on Creativity Index. Retrieved from http://www.hab.gov.hk/file_manager/en/documents/policy_responsibilities/arts_culture_recreati on_and_sport/HKCI-InteriReport-printed.pdf [Accessed 9th February 2018].

Kloudová, J. (2009) Kreativní ekonomika a její měření. Ekonomický časopis, 57(3), 247-262.

Krzysztofik, R., Tkocz, M., Spórna, T., Kantor-Pietraga, I. (2016): Some dilemmas of postindustrialism in a region of traditional industry: The case of the Katowice conurbation, Poland. Moravian Geographical Reports, 24(1), 42-54.

Lampel, J., Germain, O. (2016) Creative industries as hubs of new organizational and business practices. Journal of Business Research, 69(7), 2327-2333.

Landry, Ch. (2011) The creativity city index. City, Culture and Society, 2, 173-176.

Leriche, F., Daviet, S. (2010) Cultural Economy: An Opportunity to Boost Employment and Regional Development? Regional Studies. 44(7), 807-811.

Liu, Ch-H.S. (2018) Examining social capital, organizational learning and knowledge transfer in cultural and creative industries of practice. Tourism Management, 64, 258-270.

Lundvall, B-A., Johnson, B. (1994) The learning economy. Journal of Industry Studies, 1, 23-43.

Mackinnon, D., Cumbers, A. (2007) An Introduction to economic geography. Globalization, uneven development and place. Harlow: Pearson Education Limited.

Markusen, A., Wassall, G.H., Denatale, D., Cohen, R. (2008) Defining the Creative Economy: Industry and Occupational Approaches. Economic Development Quarterly, 22(1), 24-45.

OECD (1996) The Knowledge-based economy. Paris: OECD/GD. Retrieved from https://www.oecd.org/sti/sci-tech/1913021.pdf. [Accessed 5th February 2018].

OECD and European Commission (2008). Handbook on Constructing Composite Indicators: Methodology and User Guide, by Nardo, M. M. Saisana, A. Saltelli and S. Tarantola (EC/JRC), A. Hoffman and E. Giovannini (OECD).

Ponzini, D., Rossi, U. (2010) Becoming a creative city: The entrepreneurial mayor, network politics and the promise of an urban renaissance. Urban Studies, 47(5), 1037-1057.

Power, D. and Scott, A.J. (2004) Cultural industries and the production of culture. New York: Routledge.

Rumpel, P., Slach, O., Koutský, J. (2010) Creative industries in spatial perspective in the old industrial Moravian-Silesian Region. E\&M Economics and Management, 4/2010, 30-46.

Scott, A.J. (2000) The cultural economy of cities: essays on the geography of image-producing industries. Thousand Oaks, California: SAGE Publications.

Selwood, S. (2006) A part to play? International Journal of Cultural Policy, 12(1), 35-53.

Tafel-Viia, K., Terk, E., Lassur, S., Viia, A. (2015) Creative industries in the capital cities of the Baltic States: Are there innovations in urban policy? Moravian Geographical Reports, 23(4), $47-58$. 
Tang, W-S. (2016) Creative industries, public engagement and urban redevelopment in Hong Kong: Cultural regeneration as another dose of isotopia? Cities, 56, 156-164.

Tinagli, I. (2012) Norway in the creative age. Report 2012. Retrieved from https://www.vegvesen.no/_attachment/408714/binary/704251. [Accessed 14th February 2018].

Tinagli, I., Florida, R., Ström, P., Wahlquist, E. (2007) Sweden in the creative age. Göteborg University \& CreativityGroupeEurope: School of Business, Economics and Law. Retrieved from

http://creativeclassgroup.com/rfcgdb/articles/Sweden\%20in\%20the\%20Creative\%20Age.pdf. [Accessed 14th February 2018].

Throsby, C. (2001) Economics and culture: essays on the geography of image-producing industries. York: Cambridge University Press.

Tonev, P., Dvořák, Z., Šašinka, P., Kunc, J., Chaloupková, M., Šilhan, Z. (2017). Different approaches to defining metropolitan areas (Case study: cities of Brno and Ostrava, Czech Republic). Geographia Technica, 12(1), 108-120.

Turón, C., Gomis, J. (2016) Implementation of elements of sustainability applied to the urbanization of productive areas. Geographia Technica, 11(2), 113-124.

Van der Pol, H. (2007) Key role of cultural and creative industries in the economy. Canada: UNESCO Institute for Statistics. Retrieved from https://www.oecd.org/site/worldforum06/38703999.pdf [Accessed 14th February 2018].

Veselá, D., Klimová, K. (2014) Knowledge-based Economy vs. Creative Economy. Procedia - Social and Behavioral Sciences, 141, 413-417.

Zhong, S. (2016) Artists and Shanghai's culture-led urban regeneration: Cities, 56, 165-171. 